\title{
人工神経回路モデルと声道物理モデルを用いた 母音模倣モデルに基づく音素獲得シミュレーション
}

\author{
神田尚*尾形哲 也* 高 橋徹* \\ 駒 谷 和 範* 奥 乃 博* \\ Phoneme Acquisition based on Vowel Imitation Model \\ using Recurrent Neural Network and Physical Vocal Tract Model
}

\author{
Hisashi Kanda*, Tetsuya Ogata*, Toru Takahashi*, \\ Kazunori Komatani* and Hiroshi G. Okuno*
}

\begin{abstract}
This paper proposes a continuous vowel imitation system that explains the process of phoneme acquisition by infants from the dynamical systems perspective. Almost existing models concerning this process dealt with discrete phoneme sequences. Human infants, however, have no knowledge of phoneme innately. They perceive speech sounds as continuous acoustic signals. The imitation target of this study is continuous acoustic signals including unknown numbers and kinds of phonemes. The key ideas of the model are (1) the use of a physical vocal tract model called the Maeda model for embodying the motor theory of speech perception, (2) the use of a dynamical system called the Recurrent Neural Network with Parametric Bias (RNNPB) trained with both dynamics of the acoustic signals and articulatory movements of the Maeda model, and (3) the segmenting method of a temporal sequence using the prediction error of the RNNPB model. The experiments of our model demonstrated following results: (a) the self-organization of the vowel structure into attractors of RNNPB model, (b) the improvement of vowel imitation using movement of the Maeda model, and (c) the generation of clear vowels based on the bubbling process trained with a few random utterances. These results suggest that our model reflects the process of phoneme acquisition.
\end{abstract}

Key Words: Phoneme Acquisition, Recurrent Neural Network, Physical Vocal Tract

\section{1.は じめ に}

人間がいかに言語を獲得するかは,いまだ認知発達学におけ る謎である。この問題は, 進化言語学における研究課題の一つ とされており, 言語の起源や構造の理解を目的として盛んに研 究が行われている [1] [2]. 言語獲得研究は, 主に語裹の獲得や複 雑な文法の習得を焦点としているが, 幼児は, 言語獲得の基礎 として, 初語を発するずっと以前の段階から, すでに発声活動 (クーイングや喃語) を行っている. 近年, 脳神経科学分野の発 展により，音声生成と知覚の関連が明かにされつつあることか ら [3] [4], 幼児が音声を生成する発達過程の詳細を知ることは, これ以降の言語獲得全般を考える上で重要であると言える.

本稿では, 認知発達ロボティクス [5] の観点から, 音声模倣 シミュレーションを用いた初期音素獲得プロセスのモデル化を 行うことを目的とする。認知発達ロボティクスは, ロボットが

原稿受付 2008 年 12 月 20 日

*京都大学大学院情報学研究科

${ }^{*}$ Graduate School of Informatics, Kyoto University

一本論文は学術性で評価されました。
再現する認知発達プロセスを構成論的に検証することで, 人間 の認知に関する理解を深め, 新たなロボット技術への応用を目 的とした研究領域である。近年, ロボット工学分野において認 知発達ロボティクスと同様の考え方が広く注目されており, 口 ボットによる人間の認知・運動機能の発達的獲得を目的とした 研究が行われている $[6] 〜[8]$.

幼児は親の声の模倣を通して音声言語を獲得すると言われて いる [9]. 従来, 音声模倣インタラクションによる母音獲得研究 が行われており, 複数エージェントによるシミュレーションまた は実ロボットを用いた母音獲得過程を実現している [10]〜 [13]. これらの研究では, 音声生成時の構音運動という身体拘束条件 を考慮することで共通音素を獲得しているが, 音声インタラク ションにおける発話は 1 母音と定義されていた。つまり，音響 信号が離散的な音素列であることを前提としている。しかし， 親の子供への語りかけを考えた場合, その内容は通常言葉であ り，一母音であるケースは稀である。より自然な発達過程のモ デル化のためには, 特に「離散から連続へ問題の拡張」が必要 といえる。連続音響を対象にした際, 従来モデルでは,「未知 数・未知種類の音素が含まれる音響信号中の音素境界同定」の 
問題を解決することは難しい，例えば，音素種類が既知であれ ば，HMM などの従来法で正確な音素境界の同定が可能である が, 音素に関する知識がない状態では大変困難な問題といえる.

Kuhl ら [14] によって示されている一般的な健常幼児の生後 1 年間の音声知覚・生成発達過程を参照すると, 幼坚は, $3 \sim 5$ ケ 月期において母音様 (vowel-like) の音声生成から, 親の音声に 対して母音のみを利用した模倣を行い，6ヶ月ごろに母語に特化 した母音知覚が形成される。我々は, 幼児が音素の事前知識を 持たない状態からいかにして母国語の音素体系を獲得するかが, 初期言語獲得過程における根本的な問題であると考える.

我々は，次の二つの仮説をたてる：

仮説 1 ：人間の幼児が音声を音素列としてではなく連続音響 信号として扱う。

仮説 2 ：音素獲得には構音運動情報を用いた音声の分節化が 不可欠である.

一つ目の仮定は, 幼児が生まれながらに音響信号中の音素境 界を知らないこと, 二つ目の仮定は, 実音声は文脈に応じて同 じ音素に対する音響信号が一定パターンをとらないことに対応 する。幼览は成長するにつれて，周囲で使われる言語の韻律や リズム，アクセントを基に模倣できるか否かを試行錯誤してい くうちに，音素の単位を発見できるようになると考えられる。

本研究では, Recurrent Neural Network with Parametric Bias（RNNPB）[15] と呼ばれる人工神経回路モデルを用いて 連続音響信号と構音運動の分節化による母音獲得モデルの構築 とその検証を行った。我々はすでに, 音声を時系列ダイナミク スとして扱う音声模倣モデルを構築している [16]. この模倣モ デルでは, Maeda モデル [21] と呼ばれる人間の発声構造を反映 した声道物理モデルを用いて音声模倣を実現した。我々は, こ の音声模倣モデルに RNNPB による時系列ダイナミクス分節 化手法 [17] を適用する。 この手法は複数のシーケンスからなる 時系列ダイナミクスを RNNPB の予測誤差に基づいて分節化 を行い, 各分節区間のシーケンスを 1 組のパラメータ值として 表すことが可能である。この手法により, 連続音声中の音素遷 移がパラメータ值の切り替わりとして自己組織化されることを 期待する。

本稿では, 本模倣モデルにおける, 身体拘束（声道）を考慮す ることによる母音知覚の有効性, 音声模倣時における聴取音声 の話者性と文脈に依存する音素系列の差異判別, ランダム音声 バブリングによる幼児の音声発達過程の再現性について述べる。

\section{2. 本研究の課題}

発声は声道という身体により生成される行為であり，この身 体拘束が連続音声の構造に影響していると考えられる。つまり, 音素が滑らかにつながるのは, 発声動作において声道が連続的 な構音動作を行うためであり，この構音動作の制御に着目する ことで音素間を自然につなげることができると考えられる.

本研究では, 従来の離散的な音どおしの比較による目的の音 響信号の比較・再現ではなく, 連続的な音声と身体拘束の関係 性を考慮した音声模倣の実現に取り組む。ささらに, 音声模倣を 通じた音素構造の獲得について考察する。これらを実現するに は, 主な課題として以下の 3 点が挙げられる.

\section{課題 1 ：音声生成過程における身体拘束}

音声の連続的な構造のみでは, 音声発達過程における幼児 の構音発達過程との関連を検証することができない．その ため, 我々は音声生成モデルとして, 解剖学的知見に基づ く声道物理モデルである Maeda モデルを使用する.

母音の音響的カテゴリが発声系の筋電位特性と相関関係 を持つことを示した党らの研究 [18] や, 調音ジェスチャの 変化に対する母音のフォルマント周波数変化量が相関を示 すことを見い出した廣谷らの研究 [19] からも, 発声構造の 考慮が母音知覚形成に重要であることが分かる.

\section{課題 2 ：音声・構音動作の時系列ダイナミクス}

幼児は音素に関する事前知識を持たない. 音素の種類, ク ラス数が未知である場合, 隠れマルコフモデル（HMM）な どの統計的確率モデルを用いた音響信号パターン処理は効 率的ではない。ささらに，大量の学習データを一度に計算す る手法は, 幼児の発達過程を再現するには不適切であると 考える.

そこで, 我々は複数の時系列ダイナミクスを学習可能な 人工神経回路モデル RNNPB を使用する。 RNNPB モデ ルは, ミラーニューロンと類似した構造を持ち, 生成（順 モデル）と認識（逆モデル）を同じ機構で実現可能である. さらに RNNPB の汎化能力により未知音声に対する音声 模倣が期待できる.

\section{課題 3 : 自己組織的な母音構造抽出}

複数の音響信号中から音素境界を抽出する手法について, HMM を用いた教師なし学習の比較検討を Qiao らが行っ ている $[20]$. この手法では, 音響信号をフレームごとに分 割し, 評価関数に基づいて隣接フレームをマージすること で, 音素数・クラスを与えることなく音素境界を検出して いる。 しかし, 我々は課題 1 に示した通り, 音声が人間の 声道により生成されることを考慮するため, 時間変化が複 雑な音響パラメータの比較による分節化ではなく, 声道ダ イナミクスに着目した分節化を考える.

そこで，我々は RNN の予測可能性に基づく時系列ダイ ナミクス分節化手法を適用する [17]. 予測可能性とは, 単 一のダイナミクスから生成されたシーケンスは安定した予 測が可能であると定義される。複数の時系列パターンから 自己組織化を行いつつ共通の力学構造を抽出することによ

り，音声に含まれる母音の獲得を行う。

開発した模倣モデルは, 構音動作とその動作によって生成さ れる音声を関連付けることにより，模倣モデルが自らの身体拘 束を理解し，その経験から人間の声に対する音声模倣を行うシ ステムである.

\section{3. 母音模倣モデル}

\section{1 音声模倣プロセス概要}

本研究では, 音声・声道のダイナミクスに着目し, 連続音響 信号分節化による母音模倣モデルを構築した，本モデルは，す でに提案した音声模倣モデル [16] を基に, 構音動作と音声デー 夕を RNNPB で学習させるとともに時系列ダイナミクス分節 化手法を適用し, 各分節区間での力学構造を抽出する。さらに, 


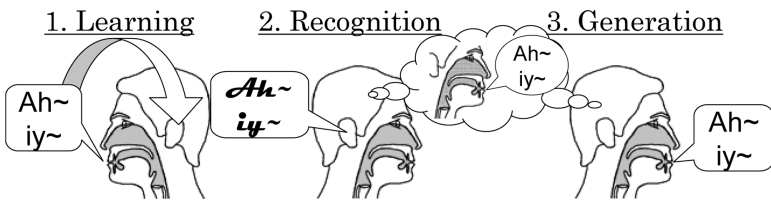

Fig. 1 Imitation process

抽出した力学構造を利用することで, 既知・未知の聴取音声が 認識可能となり，連続音声の模倣が可能となっている。

本模做プロセスを Fig. 1 に示す。模倣プロセスは学習・認 識・生成の 3 フェーズがあり，以下のと抢りである。

\section{1. 学習（音声バブリング）}

本模倣システムに構音動作を入力し, 複数母音を含む音声 を生成させ，構音動作と生成音声を関連付ける。このフェー ズは, 幼児であるシステムが「どのように声道を動かせば いかなる音声が生成されるか」を学習する “音声バブリン グ”に相当する。

\section{2. 認識（親の発声音を聴取）}

本システムに人間が発話した音声を入力し, 入力された音 声を生成するであろう構音動作を計算する。 このフェーズ は，システムが「聴取した音を自分が発話するとしたら，ど のような構音運動を行うであろうか」を認識することに相 当し, システム自らが持つ声道の身体拘束を反映した音声 認識と言える。

\section{3. 生成（聴取音に対する音声模倣）}

最後に，本システムが認識フェーズで計算した構音動作を 用いて模做音声を生成する

上記の各フェーズに扔いて，時系列ダイナミクス分節化手 法 [17] 適用する. 本模倣システムは時系列ダイナミクスとし て構音動作と音声を自己組織的に結び付けることが可能となり， 認識・生成フェーズに扔いて，この関倸性を利用する。

\section{2 解決策 1 : 声道物理モデル}

人間の発声機構を模擬する音声生成モデルでは, 発声器官の 幾何学的構造とその力学的な構造に起因する制約や音声生成に かかわる音響的な制約が組み込まれており，人間の発話動作を 真似たより自然なパラメータ制御が期待できる。 また，パワー スペクトルなどの音響パラメータでは, 時間変化が複雑で音素 間の変化パターンを簡単に補間することが困難であるのに対し, 物理的な制約のある発声器官の運動に基づく構音パラメー夕は 時間的に連続で滑らかに変化し, 連続音声の合成に有利である。 本模倣システムには, Maedaにより提案された声道物理モデ ル [21] を用いる. このモデルは, 母音生成時の声道器官の正中 矢状面をレントゲン撮影し, 形状を $\mathrm{N}$ 点分割した後の主成分分 析により得られた七次元パラメータを持つ。これら七つのパラ メー夕を設定することで声道形状を決定し，それに対応する音 声を生成することができる，Maeda モデルの七次元パラメー夕 を Table 1 に示す. 各パラメー夕は $+3 \sim-3$ の実数值により 表現され，その值の増減に対して，次の関係が成り立つ：JP) 顎位置の上下，TDP）舌背位置の前後, TDS）舌背位置の上下， TTP）舌尖の上下，LO）唇の開閉，LPR）唇位置の前後，LP） 喉頭位置の上下.
Table 1 Parameters of the Maeda model

\begin{tabular}{clcll}
\hline Number & Name & value: +3 & $\cdots$ & -3 \\
\hline 1 & Jaw position (JP) & upper & $\leftrightarrow$ & lower \\
2 & Tongue dorsal position (TDP) & forward & $\leftrightarrow$ & back \\
3 & Tongue dorsal shape (TDS) & upper & $\leftrightarrow$ & lower \\
4 & Tongue tip position (TTP) & upper & $\leftrightarrow$ & lower \\
5 & Lip opening (LO) & close & $\leftrightarrow$ & open \\
6 & Lip protrusion (LPR) & forward & $\leftrightarrow$ & back \\
7 & Larynx position (LP) & upper & $\leftrightarrow$ lower \\
\hline
\end{tabular}

Table 2 The F1 and F2 averages of the Maeda model

\begin{tabular}{c||c|c|c|c|c}
\hline & $/ a /$ & $/ i /$ & $/ u /$ & $/ e /$ & $/ o /$ \\
\hline F1 & 667 & 234 & 269 & 401 & 500 \\
\hline F2 & 1214 & 2161 & 924 & 1894 & 902 \\
\hline
\end{tabular}

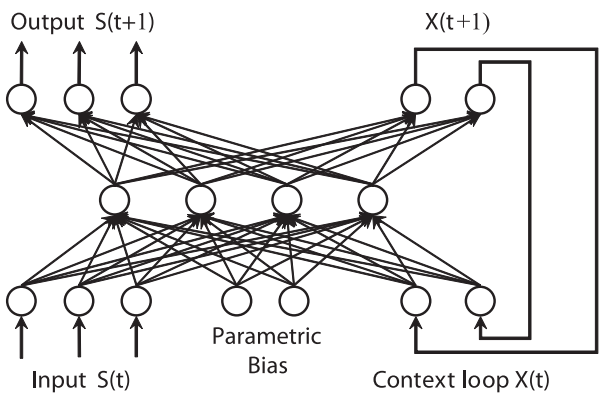

Fig. 2 RNNPB model

音声生成可能な声道モデルには, ほかにも PARCOR [22] や Mel-Cepstrum [23], 極めて高精度の音響再現機能を持つ STRAIGHT [24] などがある. しかし, 本研究では, 人間の認知 発達過程をシミュレートするため, 解剖学的知見に基づく Maeda モデルが適切であると考えられる。

Table 2 は, Maeda モデルが生成する定常母音の第 1 ・第 2 フォルマント（F1，F2）の平均值を示す.

\section{3 解決策 2 : 人工神経回路モデル RNNPB}

我々は，谷ら [15] によって提唱された Fig. 2 のような Parametric Bias（PB）を持つ RNN を人工神経回路モデルとして 用いる.このモデルは, 現状態を入力として次状態を出力とす る予測器と見なすことができる，RNNPB は再帰結合を持ち， 非線型な時系列パターンを学習することができる，さらに，PB 值を変更することで，一つの RNNPB に複数の時系列パ夕ー ンを埋め込むことが容易となり, 各時系列パターンに対応した $\mathrm{PB}$ 值を $\mathrm{PB}$ 層に入力することで求めるパターンを出力させる ことができる，また，学習に時間がかかる反面，少量の学習デー 夕で汎化可能という利点がある.

\section{4 解決策 3 ：RNNPB による時系列ダイナミクス分節 化手法}

適用する時系列ダイナミクス分節化手法は，RNNPB の予測 誤差を用いて分節位置を決定する，具体的には，単一のダイナ ミクスから生成されたシーケンスは安定した予測が可能である という「予測可能性」を利用する。

RNNPB は，ある一定の PB 值が与えられている際のダイナ ミクス特性は同一である. 単一の PB 值で予測可能なシーケン ス，すなわち単一のダイナミクスから生成されたシーケンスで 


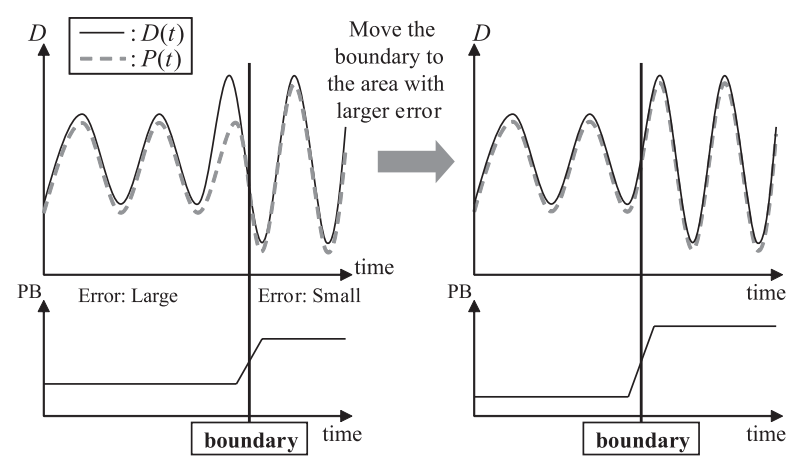

Fig. 3 Segmenting multiple dynamics

は，予測が成功するためエラーは小さくなる。一方，複数のダ イナミクスから生成されたシーケンスでは, ダイナミクスが切 り替わる際に予測エラーが大きくなる。この予測エラーを分節 化に利用する，概念図を Fig. 3 に示す.

以下, 総ステップ数が $T$ である時系列データ $D(t)(t=$ $1,2, \cdots, T)$ を, $N$ 個の区間 $S_{0}, S_{1}, \cdots, S_{N-1}$ に分節化する手 順を述べる。 また，区間 $S_{i-1}$ と $S_{i}$ の境界を $t=s_{i}$ とする。 すなわち, $i$ 番目の区間 $S_{i}$ は, 区間 $\left[s_{i}, s_{i+1}\right]$ となる.

手順 1 : 初期化

入力されたシーケンスを $N$ 等分する. 境界 $s_{i}(i=0, \cdots, N)$ は以下のように求める.

$$
s_{i} \longleftarrow i \cdot T / N
$$

手順 2 : RNNPB の学習

ニューラルネットの結合重みと PB 值を更新する。このとき, 各区間 $S_{i}$ での PB 值は一定である.

手順 3 : エラーの算出

各ステップで, RNNPB の予測值 $P(t)(P(t)$ は, Fig. 2 における $S(t+1))$ を算出し, 各区間における平均誤差 $E_{i}(i=0, \cdots, N-1)$ を以下のように求める.

$$
E_{i} \longleftarrow \frac{1}{s_{i+1}-s_{i}} \cdot \sum_{t \in S_{i}}\|D(t)-P(t)\| .
$$

手順 4 : 区間幅の更新

境界 $s_{i}(i=1, \cdots, N-1)$ を以下のように更新する。ここ で, $d s$ は境界の更新幅である。

$$
s_{i} \longleftarrow \begin{cases}s_{i}-d s & \text { if } E_{i-1}>E_{i} \\ s_{i} & \text { if } E_{i-1}=E_{i} \\ s_{i}+d s & \text { if } E_{i-1}<E_{i},\end{cases}
$$

手順 5: 手順 2 から 4 を学習が収束するまで繰り返す.

RNNPB はダイナミクス予測器であるため, 二つ以上の音韻 遷移, 定常状態を一つのPB で表現できる。例えば, 学習デー 夕が, /aiu/, /aie/の場合は, /ai/の部分が一つの PB で表 現される.しかしここに/aeu/のような学習データを加えるこ とで, $/ a /$ と $/ i /$ の境界で予測エラーが大きくなり, 分節位置 が現れることになる。十分に多様なデー夕を与えることで適切 な母音位置が得られる。

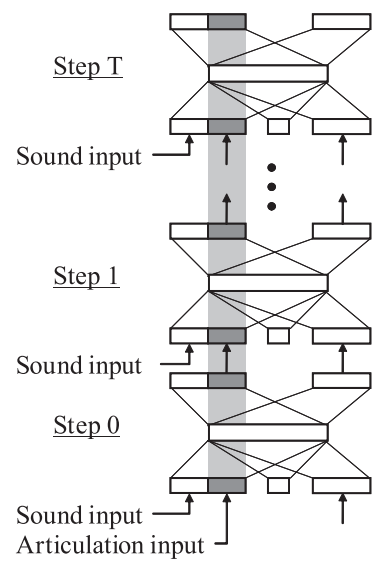

Fig. 4 Calculation in the recognition phase

\subsubsection{PB 值学習方法}

本研究では, 各分節区間ごとに $\mathrm{PB}$ 層の内部值を求める. $\mathrm{PB}$ 層の内部值はニューロンの結合重み・閾值と同様に, 時刻 $t$ ご とに出力 (予測) 誤差から学習信号を求め, Backpropagation through time (BPTT) [25] を行うことにより計算される. 入 カシーケンスの $i$ 番目の分節区間 $S_{i}$ の長さは $s_{i+1}-s_{i}$ であ $\eta, S_{i}$ の $k$ 番目の $\mathrm{PB}$ 值は以下のように求める. ここで, $\varepsilon$ は 学習定数である.

$$
\begin{aligned}
\delta \rho_{i, k} & =\varepsilon \cdot \sum_{t=s_{i}}^{s_{i+1}} \delta_{i, k}(t), \\
p_{i, k} & =\operatorname{sigmoid}\left(\rho_{i, k}+\delta \rho_{i, k}\right),
\end{aligned}
$$

式（4）で, 区間 $S_{i}$ における学習信号は，それぞれの PB 值 $\rho_{i, k}$ に対して各ステップにおけるエラー $\delta_{i, k}$ の総和 $\delta \rho_{i, k}$ とし て計算される.この学習信号 $\delta \rho_{i, k}$ を現在の内部值に加算して からシグモイド関数に通して出力される值 $p_{i, k}$ を $\mathrm{PB}$ 值とする.

3.4 .2 認識・生成時の計算手法

学習ずみ RNNPB を用いて, 以下のように時系列データの 認識ができる。認識対象の時系列データをステップごとに入力 し, 出力される予測值と実際の值の誤差を求める. この際コン テキスト層の初期值は全データで共通である。その誤差を利用 し, 結合重みを固定した状態で, BPTT 法により PB 值のみ修 正する. この結果得られた $\mathrm{PB}$ 值は, 入力時系列に対応した值 となる。

入力音声の認識フェーズにおいては, 学習時とは異なり構音 パラメータは入力されず, 音声パラメータのみ入力される. そ こでステップ 1 において構音パラメータの標準值 (Maeda モデ ルの七次元べクトルすべてが 0）のみを与え, それ以降のステッ プでは閉ループにより構音パラメータの計算を行う（Fig. 4 参 照). BPTT においては, ステップ $t+1$ における構音パラメー 夕の出力を, ステップ $t$ における入力とする. つまり構音パラ メータノードは他のコンテキスト層と同様に扱われる.

RNNPB を用いた時系列データの生成方法を，Fig. 5 に示 す. 入力層, コンテキスト層に, 時系列データの初期值（認識 時に使用した標準值), $\mathrm{PB}$ 層に生成対象の時系列データの $\mathrm{PB}$ 值を入力する. 次ステップの予測值を出力し, この予測值を再 


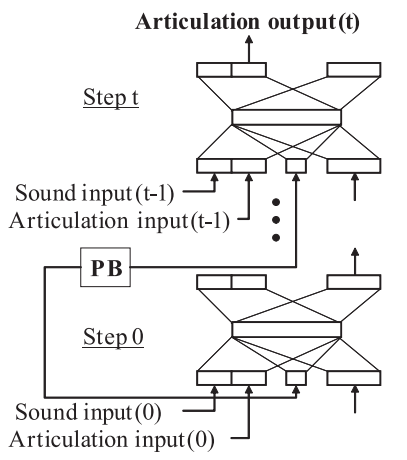

Fig. 5 Calculation in the generation phase

帰的に入力層に与えることにより，PB 值と初期值に依存した 時系列デー夕の予測值を生成することが可能となる.

各区間の接続部では，認識時に得られた $\mathrm{PB}$ 值 $p_{i}$ を各区間 境界 $s_{i}$ に入力（区間内で一定）し, 各区間ステップ 0 の入力 層に前区間最後の音声 ・構音パラメー夕值を入力する. 以上の プロセスにより, 認識された入力音声に対する模做音（構音パ ラメータ）を得ることができる。

\section{4. 音声模倣システム}

本模倣モデルのシステム設計について述べる，模倣システム の概観はFig. 6 のとおりである. 以下に, 模做システムの概要 と, 本稿で扱う特徵量, その作成方法にについて述べる.

\section{1 模倣システムの概要}

本システムにおける音声模倣の手順は以下のとおりに行う。ま ず, 学習フェーズに扔いて, 時系列構音パラメータを 4.2 .1 項で 説明する方法によって求め, それを Maeda モデルに入力するこ とで音声を出力させる. 出力した音声を音声パラメータ（Sound parameters：SPs）に変換し, 得られた各音声パラメータとそれ を生成する構音パラメータ（Articulatory parameters：APs） を用いて RNNPB の重みを学習させる。

次に，認識フェーズに执いて，人がマイクから入力した音声 を音声パラメー夕に変換し, 音声パラメータのみを RNNPBに 入力する。 このとき, 学習時に構成した RNNPB の重みは固 定し, PB 值のみを計算する.

最後に, 認識時に得られた PB 值を構成済みの RNNPB に 入力することで構音パラメータを求め, その構音パラメータを Maeda モデルに入力し模倣音声を得る。

\section{2 使用する特徵量}

\subsection{1 構音パラメー夕 $(\mathrm{APs})$}

Maeda モデルの各母音に対する構音パラメータは求められて いる。 また, Maeda モデルはある時間間隔で構音パラメー夕を 指定すると, その間の構音パラメー夕を線形的に補間し, 滑ら かな音声を生成することが可能である. 本システムでは構音表 パラメータとして 1 の 1 6 番を用いる. 7 番目のパラメータ LP は母音発音時に一定值をとるため, 本実験では扱わない．

Maeda モデルは時間的変化に対する構音制御制約がないた め, 本実験において, 時間軸に対して身体拘束処理を施してい る. 例えば, RNNPB から出力された構音パラメータが激しく 時間変動する場合がある。これは, 未知音声に対する声道挙動

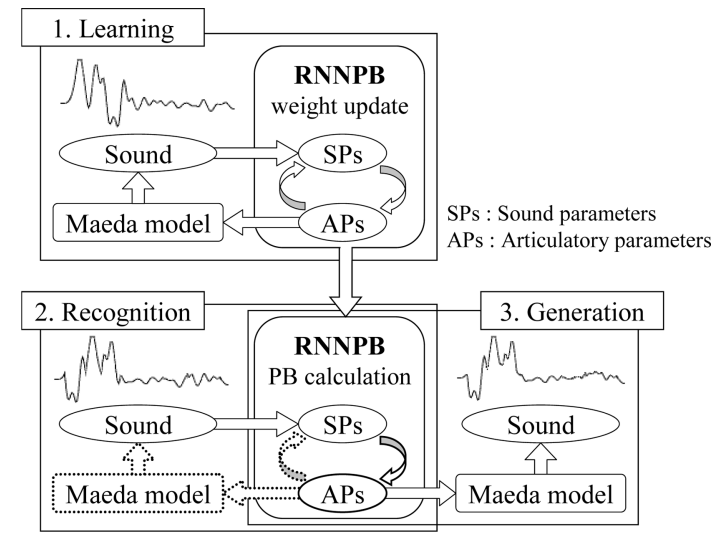

Fig. 6 Diagram of the experimental system

の予測困難により生じるもので, 声道モデルの物理的な制御の 許容限度を越えるものである。このため, 生成フェーズにおける 身体拘束処理として, 隣り合うステップで急激な変動による発 声動作を抑制するため, 時間軸に対して構音パラメータの平滑 化処理を行った，具体的な計算方法は以下のと㧍りである．各 ステップの構音パラメータと, その前後のステップのパラメー 夕を合計し，平均した值をそのステップのパラメータとした。

4.2 .2 音声パラメータ ( $\mathrm{SPs})$

我々は音声パラメータとして STRAIGHT 分析により得ら れた Mel-Frequency Cepstrum Coefficients (MFCCs) の一 種 [24] を用いた。一般的に, MFCCs は短時間フーリエ変換に よるパワースペクトルから計算されるが, 声帯振動が生み出す 基本周波数の違いにより個人間の韻律の違いの影響を受けやす い. そこで音声パワーのメルフィルタバンク処理後に離散コサ イン変換を行った. このSTRAIGHT 分析は, 基本周波数に応 じた分析空幅を設定するピッチ分析を行うため, 基本周波数に 独立で骬らかな゚ワースペクトルを求められる. 以上により, 個 人間の韻律の違いを除去,つまり声道長を正規化したのと同様 の MFCCs が得られる.

以下，本実験に扔いて，サンプリング周波数 $10[\mathrm{kHz}], 1$ チャ ンネルの音声波形を使用する. フィルタバンク数を 12 に設定 し, MFCCs 分析により得られた 12 次元音声パラメータのう ち, 低次から数えて三〜七次元の五次元パラメータを用いた. この音声特徴量は, MFCCsの一, 二次元に含まれるスペクト ル傾斜を除去することで，母音の特徵を保持しつつ, 基本周波 数成分（F0）の除去を行ったパラメータとなっている. 本稿で は，音声の抑揚について扱わないため，上記の処理を行った。

\section{5. 評 価 実 験}

本研究で提案した音声模做モデルを用いて音素獲得シミュレー ションを行った. 条件として, システムに音素数や音素クラス についての事前知識は与えない. 本実験では学習フェーズにお いて分節数 $N=8$ とし, 境界更新幅 $d s$ は重み学習 10 回につ いて 1 移動させた。認識フェーズでは RNNPB の予測エラー が小さくなるよう各入力データに対して $d s, N$ を変化させた. 具体的には, 具体的には, デー夕全体のエラーが減少するに従っ て $d s$ を減少させ, $N$ は全体エラーが収束しない場合に増加さ 
Table 3 Input sound data in the recognition phase

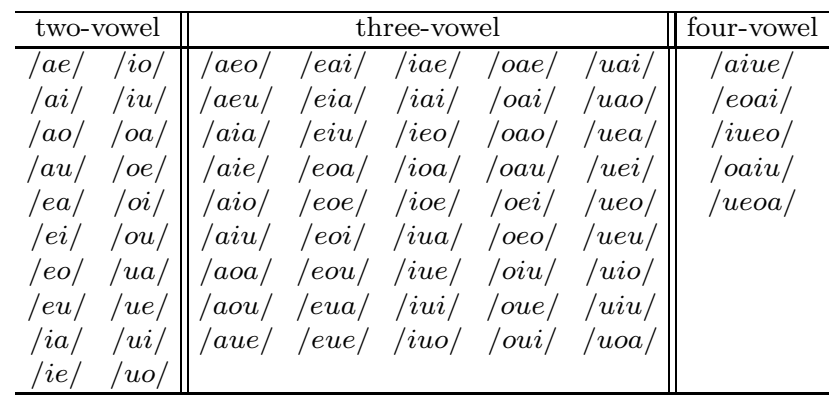

せた。

以下に，本模倣モデルにおける学習フェーズについて，2 種 類の音声バブリング条件で音声模做実験を行った。実験 1 で は, Maeda モデルによりすでに決定されている母音の声道形状 (Maeda モデル母音) を用いて, 学習用の構音·音声ダイナミクス を作成し, 声道情報を考慮することによる母音知覚の有効性と音 声模做能力について示す. 実験 2 では, ランダムに設定した構音 パラメータを用いて学習デー夕を作成することで, ランダム音声 バブリングによる幼児の音声発達過程の再現性について述べる.

\section{1 実験 1 : Maeda モデル母音を用いた音声バブリング学 習による音声模倣}

\subsection{1 実験条件 1}

学習フェーズにおいて，Maeda モデルにより生成された 10 パターンの 3 連続母音構音・音声デー夕（各 1,350 [ms], $30[\mathrm{~ms} / \mathrm{step}]$ ）を作成した。学習データパターンは次のとおり： /aiu/,/iue/,/ueo/, /eoa/, /oai/, /iao/,/aoe/,/oeu/, /eui/, /uia/. 学習時の各音素のフォルマントは, Table 2 の と㧍りである。次に，二つの RNNPB を用意し，一方は音声 デー夕のみを学習する RNNPB-1, もう一方は構音・音声デー 夕を学習する RNNPB-2 と呼ぶ. 各 RNNPB の入出力層は, RNNPB-1 が五次元, RNNPB-2 は 11 次元であり, 入出力層 以外は同じ構成となる（中間層 40 次元，文脈層五次元，PB 層 二次元).

認識フェーズでは, 男性話者 3 名（話者 $1,2,3)$ について 各 70 発話を行い, それら 210 発話の音声に対する音声パラメー 夕を学習ずみの RNNPB にそれぞれ入力した，入力された 70 発話は Table 3 のと扔りであり, 2 母音音声（各 $900[\mathrm{~ms}]$ ): 20 種類, 3 母音音声 (各 $1,350[\mathrm{~ms}]$ ) : 45 種類, 4 母音音声（各 $2,000[\mathrm{~ms}]): 5$ 種類となっている。

さらに，RNNPB-2 においては，生成フェーズを行い，認識 フェーズで得られた各区間の境界位置と PB 值を用いて構音パ ラメータを求め, 入力音声に対応する模倣音声を生成した.

\section{1 .2 実験結果 1}

Fig. 7 に, 学習デー夕例 / aiu/を示す. 11 次元のうち四次元 (Maeda モデルの JP と TDP, MFCCs の三・四次元目のシー ケンス）をプロットしている。この学習データの RNNPB-1 に は音声情報のみ, RNNPB-2 には音声・構音情報が入力される.

Fig. 8 は，RNNPB-2 の学習データ/aiu/に対する PB 值変 化である. 各区間 $S_{i}(i=0, \cdots, 7)$ を示しており, 垂直な 点線により示している境界位置はそれぞれ $s_{1}=2, s_{2}=14$,

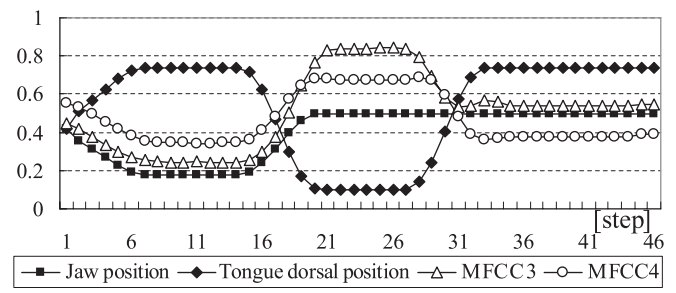

Fig. 7 Learning data: /aiu/

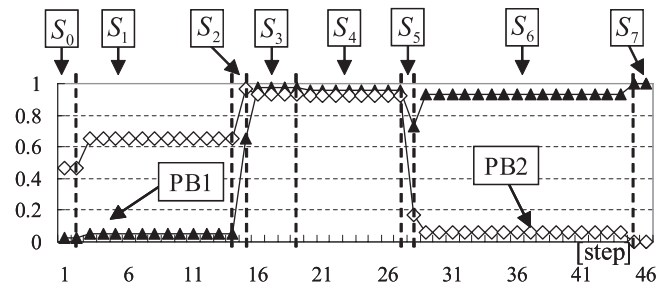

Fig. 8 The PB values of /aiu/ in the learning phase
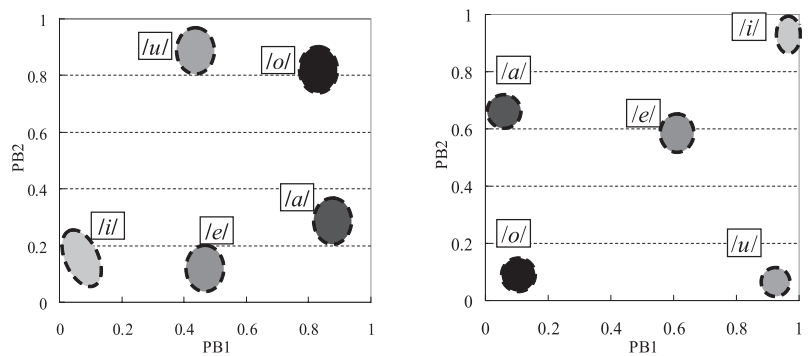

Fig. 9 PB space in the learning phase (Left: learning only SPs, Right: learning SPs and APs)

$s_{3}=15, s_{4}=19, s_{5}=27, s_{6}=28, s_{7}=44$ である. Fig. 7 , 8 を比較すると, 入力シーケンスの母音に対応する定常部分（区 間 : $\left.S_{1}=\left[\begin{array}{ll}s_{1} & s_{2}\end{array}\right], \quad S_{4}=\left[\begin{array}{ll}s_{4} & s_{5}\end{array}\right], \quad S_{6}=\left[\begin{array}{ll}s_{6} & s_{7}\end{array}\right]\right)$ と母音間の 遷移部分（区間： $S_{0}=\left[\begin{array}{ll}s_{0} & s_{1}\end{array}\right], S_{2}=\left[\begin{array}{ll}s_{2} & s_{3}\end{array}\right], S_{3}=\left[\begin{array}{ll}s_{3} & s_{4}\end{array}\right]$, $S_{5}=\left[\begin{array}{ll}s_{5} & s_{6}\end{array}\right], \quad S_{7}=\left[\begin{array}{ll}s_{7} & s_{8}\end{array}\right]$ を分けるように分節化が行われ ている，さらに，遷移部分よりも定常部分が幅広い区間を占め て抢り,これらの結果は他の学習デー夕に対して RNNPB-1, RNNPB-2 両方とも同様の結果となった.

Fig. 9 は，学習フェーズで各 RNNPB が母音を自己組織化 した PB 空間領域を示している. PB 空間は強い非線形性を有 するため, 厳密な信頼領域は得られないが, 獲得された母音は それぞれこれらの領域に集中した，左図が RNNPB-1，右図が RNNPB-2 の自己組織化結果を表している. Fig. 9 の PB 空間 上には，各学習デー夕に扔ける母音定常区間を表す PB 值の分 布を示している。ここでは PB 值が执よそ 5 ステップ以上に 渡って変化しなかった区間を母音定常区間とした，学習データ 例 / aiu/については, Fig. 8 中の $S_{1}, S_{4}, S_{6}$ の PB 值に相 当する. 他の学習デー夕について同様に対応させている. Fig. 9 から，RNNPB-1，2 のどちらの場合も複数の学習デー夕に内在 する同じ母音がほぼ同じ PB 值で表現され，異なる母音の PB 值は十分な間隔を持って PB 空間上に位置していることが確認 できる.

Fig. 10 は，認識フェーズの話者 2 の音声入力 / aiu/につい 


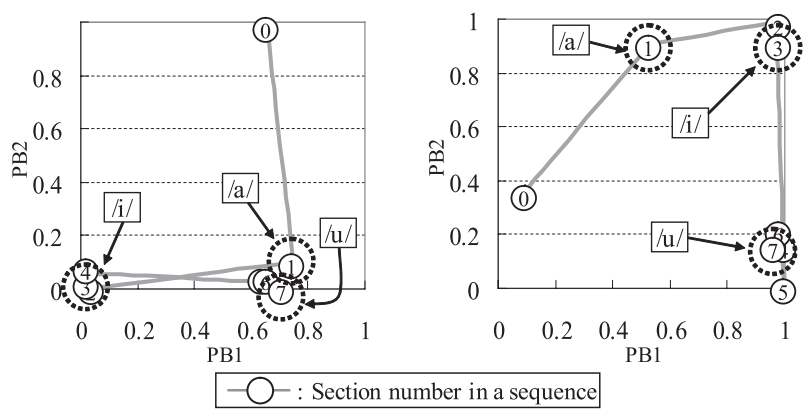

Fig. 10 PB sequence of /aiu/ for Speaker 2 (Left: learning only SPs, Right: learning SPs and APs)
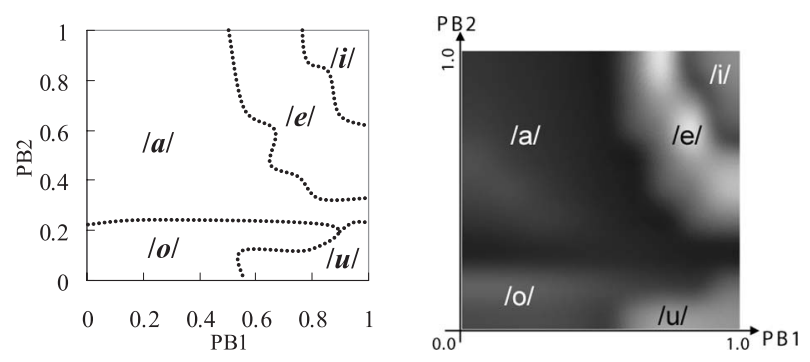

Fig. 11 Analysis of PB space

て, 各 RNNPB の認識時（分節数 $N=8$ ）に得られた PB 值 の変化を PB 空間上に示している. 左図が RNNPB-1, 右図が RNNPB-2 の認識結果を表している，母音定常区間に対応する 区間は, RNNPB-1, 2 ともに $S_{1}=/ a /, \quad S_{3}=/ i /, \quad S_{7}=/ u /$ となった. RNNPB-1 の場合, Fig. 9 左図の自己組織化結果に 対し, $\mathrm{PB}$ 空間上に扔いて母音 $/ u /$ の PB 值が $/ e /$ と誤認識 されている。一方, RNNPB-2 の場合, 母音 $/ a /$ の PB 值が /e/ に近付いているものの, Fig. 9 右図の自己組織化結果とほ ほ同じ空間付近に母音定常区間の PB 值が存在している.

RNNPB-1 は音声信号のみを入力・出力（予測）するのに対 し, RNNPB-2では, 音声信号と構音動作を入出力する。 学習時 に構音動作情報を利用したかどうかで, RNNPB-1 と 2 の PB 空間の構造が異なり，これが二つの図の差となって現れている.

Fig. 11 は, RNNPB-2 により自己組織化した PB 空間の解 析結果を示している。解析手順は以下のと抢り.

（1） PB 空間を $10 \times 10$ の格子状に分割.

（2）分節数 $N=1$ として, 生成フェーズと同様に各格子点の $\mathrm{PB}$ 值から構音パラメー夕を生成.

（3）構音パラメータを Maeda モデルに入力し， $300[\mathrm{~ms}]$ の音 声を生成.

（4）生成音の第 $1 \cdot 2$ フォルマントの平均值を計算.

（5）Table 2 の各母音と生成音のフォルマントの 2 乗誤差を算出.

（6）誤差最小の母音を各格子点の代表母音に設定.

RNNPB-1 には構音動作の出力（生成・予測）能力がないため, 対応する音声を得られず，このような図を示すことはできない。 各格子点は明確に各母音に割り振られるわけではなく, Fig. 11 右図のように曖昧な境界を持った領域が形成される。これ以降は 見易さ，議論のしやすさから境界をあえて提示し，Fig. 11 左図 のように示す. Fig. 9 右図と比較すると, 定常母音を表す PB 值
徹 駒 谷 和 範 奥 乃 博

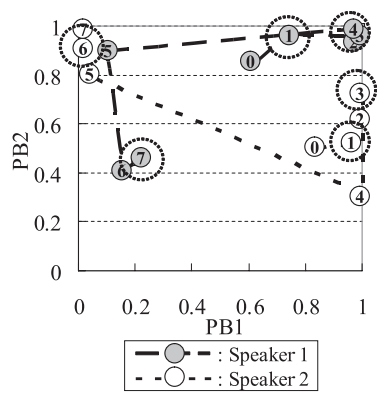

Fig. 12 PB sequences of /eia/for Speaker 1 and 2 in the recognition phase

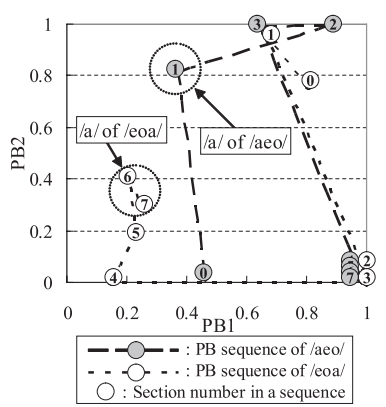

Fig. 13 PB sequences for /aeo/ and /eoa/ of Speaker 3

を基に周辺に広がりのある分布を形成しており，特に，母音 $/ a /$ を表す空間が広くなっていることが確認される。また，Fig. 10 右図と比較すると，やはり，母音定常区間を表す PB 值は各母 音を表す PB 空間上に配置されている.

RNNPB-2 の生成フェーズにおいては, 全 280 発話の音声入 力中 7 割程度が明暸な模做音声を生成した。 この判定は複数人 により行った. Fig. 12 は, 話者 1，2の発話 / eia/に対する $\mathrm{PB}$ 值の変遷を, $\mathrm{PB}$ 空間上に示している.これらの音声入力 については分節数 $N=7$ で認識しており, 各話者の $\mathrm{PB}$ 值遷 移には 0 7 の区間番号が記してある。話者 1 については区間 $S_{1}, S_{2}, S_{7}$, 話者 2 は $S_{1}, S_{3}, S_{6}$ の区間幅が大きく, それぞ れの区間の PB 值が, Fig. 11 に扔ける母音 / e/, / / i , / / / に 対応していることが確認できる. 同じ母音列に対して, 話者の 違いによる PB 值の遷移が変化するという結果が得られた。

また, Fig. 13 は話者 3 に扔ける入力音声 / aeo/ と/eoa/に 対する $\mathrm{PB}$ 值の変遷を PB 空間上に示している，定常母音 $/ a /$ に対応する区間は/aeo/の場合 $S_{1}$, / eoa/ は $S_{7}$ である。これ らの区間に対する PB 值は，Fig. 11 に抒いて $/ a /$ を表す空間 に位置しているが，同一話者についても模倣対象の母音列の並 びの違いによる影響が確認できる，同様の議論は 2 音素列 / eo/ についても言える.

Fig. 14 は, F1-F2 空間上に, 話者 3 に対する 2 母音模做音 声の各定常母音区間における平均フォルマントをプロットした ものである. Table 4 に示した話者 3 の各母音の平均フォルマ ントと模做音の各フォルマントを比較すると, 母音 $/ o$ / が著し く離れていることが確認される。 また, Fig. 13 において, 話者 $3 の /$ aeo/の $/ o /$ に対する区間は $S_{4}$ であり，この区間を表す PB 值は Fig. 11 の $/ u /$ の空間に対応している。 これらの結果 


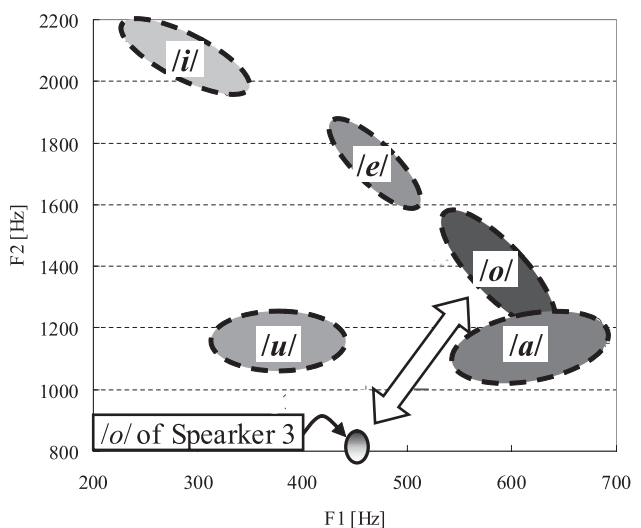

Fig. 14 F1-F2 in the recognition phase of Experiment 1

Table 4 The F1 and F2 averages of Speaker 3

\begin{tabular}{c||c|c|c|c|c}
\hline & $/ a /$ & $/ i /$ & $/ u /$ & $/ e /$ & $/ o /$ \\
\hline F1 & 720 & 274 & 297 & 449 & 451 \\
\hline F2 & 1,231 & 2,190 & 1,108 & 2,064 & 818 \\
\hline
\end{tabular}

Table 5 The F1 and F2 of learning data-set 1

\begin{tabular}{c||c|c|c|c|c}
\hline & $/ v 1 /$ & $/ v 2 /$ & $/ v 3 /$ & $/ v 4 /$ & $/ v 5 /$ \\
\hline $\mathrm{F} 1$ & 716 & 330 & 381 & 558 & 493 \\
\hline $\mathrm{F} 2$ & 1,144 & 2,027 & 1,135 & 1,639 & 1,044 \\
\hline
\end{tabular}

から，母音 $/ o /$ に対する音声模倣が困難な状況となっているこ とが確認された。この結果は, 他の話者についても同様である.

\section{2 実験 2 : ランダムバブリング学習による音声模倣}

5.2 .1 実験条件 2

学習フェーズにおいて, 構音パラメータをランダムに変化さ せたもののなかから 10 種類の音素を選び出し, それらを用い て 2 セットの学習データを作成した。選出した各音素を $/ v_{i} /$ $(i=1, \cdots, 10)$ で表現し, 学習セット 1,2 の音素群をそれぞ れ $/ v_{1} / \sim / v_{5} /, \mid v_{6} / \sim / v_{10} /$ とする. これらはランダム音で あるため明瞭な母音ではない. Table 5, 5 に, 学習セット 1 , 2 の音素群の F1-F2 を示し, Fig. 15 にそれぞれフォルマント 空間上での配置を示す. 各セットにおける学習データパターン は，それぞれ以下に示す 10 種類（各 1,350 [ms], 30 [ms/step]） である。

set 1: $/ v_{1} v_{2} v_{3} /, / v_{2} v_{3} v_{4} /, / v_{3} v_{4} v_{5} /, / v_{4} v_{5} v_{1} /, / v_{5} v_{1} v_{2} /$, $/ v_{2} v_{1} v_{5} /, / v_{1} v_{5} v_{4} /, / v_{5} v_{4} v_{3} /, / v_{4} v_{3} v_{2} /, / v_{3} v_{2} v_{1} /$.

set $2: / v_{6} v_{7} v_{8} /, / v_{7} v_{8} v_{9} /, / v_{8} v_{9} v_{10} /, / v_{9} v_{10} v_{6} /, / v_{10} v_{6} v_{7} /$, $/ v_{7} v_{6} v_{10} /, / v_{6} v_{10} v_{9} /, / v_{10} v_{9} v_{8} /, / v_{9} v_{8} v_{7} /, / v_{8} v_{7} v_{6} /$.

学習セット 1,2 は音素群の広がりが異なっており, これは声道 の可動範囲の違いに対応している. 舌の上下運動について, 学 習セット 1 は可動域が広く, 学習セット 2 は可動域が狭い.

学習フェーズにおいて, 以上で設定した学習データセット 1,2 について，それぞれ二つの RNNPB（RNNPB-3, RNNPB-4： 入出力層五次元, 中間層 40 次元, 文脈層五次元, $\mathrm{PB}$ 層二次元) に学習させた。認識・生成フェーズでは, 話者 3 のみ Table 3 の音声データについて行った。

\section{2 .2 実験結果 2}

学習フェーズにおいて, 各学習セットについて自己組織化され
Table 6 The F1 and F2 of learning data-set 2

\begin{tabular}{c||c|c|c|c|c}
\hline & $/ v 6 /$ & $/ v 7 /$ & $/ v 8 /$ & $/ v 9 /$ & $/ v 10 /$ \\
\hline F1 & 684 & 274 & 300 & 474 & 478 \\
\hline F2 & 1,375 & 1,690 & 1,435 & 1,433 & 1,108 \\
\hline
\end{tabular}
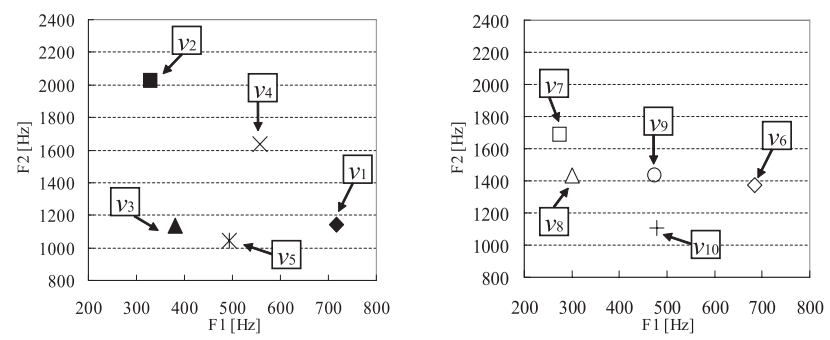

Fig. 15 F1-F2 for learning phoneme sets (Left: data-set 1, Right: data-set 2)
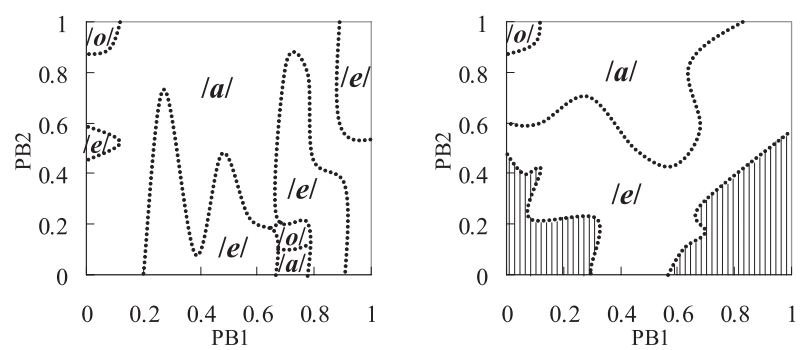

Fig. 16 PB space in the learning phase (Left: data-set 1, Right: data-set 2)

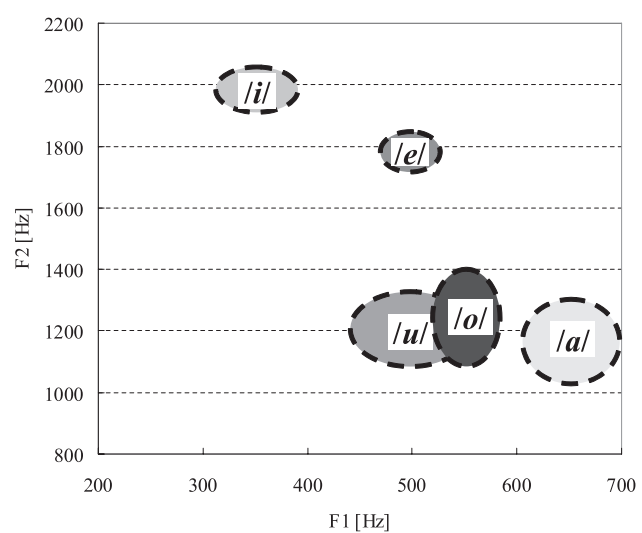

Fig. 17 The F1-F2 in the recognition phase of Experiment 2

た PB 空間の解析結果を Fig. 16 に示す. 解析手順は, 実験 1 の 時に行ったものと同じである.Fig. 16 右図の掛線部分は音声が 生成されなかった空間を表している，Fig. 16 から，RNNPB-3, 4 の両方とも $/ a /$ と $/ e /$ の PB 空間が広く形成されているが, 舌の上下可動域の制約により構音・音声学習が不十分であった学 習セット 2 については, 自己組織化できない空間が形成された.

生成フェーズにおいて, 学習セット 2 を学習した RNNPB4 については，ほぼすべての入力音声について模倣音声を生成 できなかった。これに対して RNNPB-3では, RNNPB-2 と 同程度の明瞭さで模倣音声を生成することができた，Fig. 17 は, RNNPB-3 を用いて 3 母音音声模倣を行った際に生成され た音声中の各母音定常区間に対する F1-F2 分布を示している. 
Table 4 に示す入力音声の F1-F2 と比較すると, / $/$ /, /o/の 定常区間と判別された模做音声が本来の F1-F2 に対して離れ た值をとっている。

\section{6. 考察}

\section{1 音声知覚における声道情報利用の有効性}

本実験から, 声道情報追加による母音知覚の精度向上が示唆 された. Fig. 9 と Fig. 10 の比較から, 音声情報のみの認識よ りも，構音情報を用いることで，話者の違いに対するロバスト な母音認識が確認できる.

我々はすでに声道長正規化処理を行わない場合の検証もして いる [30]. この研究では話者の違いに対して, 特に $/ o /$ と $/ a /$ の識別能力が, 声道モデルの有無により顕著に異なることを示 している.

従来, 言語処理過程に扔ける音声知覚・生成の関連性が議論 されており, 本稿で構築した母音模倣モデルは, 音声知覚の運 動理論 (motor theory of speech perception, 以下, 運動理論) として提唱されてきた理論の検証モデルであると言える.

運動理論の基本的な主張内容は次のと抢りである。，その基本 的な主張は以下の二つである $[26]$.

（1）音声知覚は，聞き手が積極的に音声を聞き取るための能動 的処理であり, 音声のための特別な知覚機構, 「音声モード (speech mode)」が存在する.

(2) 音声知覚は基本的に音声生成過程を介して行われる.

つまり，聞き手が「聴取した音声を自分が発話するとしたら，ど のような調音運動を行うか」という自分の調音器官の運動感覚, さらには, 神経制御指令 (motor command) レベルで音声知 覚を行っているとする理論である。この理論は, 音声知覚を音 声生成と常に結び付けて考え, 聞き手は一方では話し手であり， 両者ができるだけ一つの共通した言語処理過程を使ったほうが 合理的であろう，という考えに根ざしている。

運動理論が提唱されて以来，音声モードの存在に対する疑問 も出されている [27]. しかし近年, 認知神経科学の急速な発展に よって, 運動理論の神経基盤につながる発見が相次ぎ, 運動理 論を支持する知見が多く得られている [28] [29]. また江尻ら [32] は，構音障害と聴覚障害それぞれに㧍ける言語発達の遅れにつ いて報告している。

さらに音響特徽と声道特徵を同時に利用することで音声認識 率が向上することは [31] などいくつかの工学モデルが報告され ている.これらの研究では声道情報を既知として与えているが， 本研究では RNN を用いて “音響信号のみから声道ダイナミク スを連想”して音声知覚能力を向上させる点に特徴がある.

つまり，本稿の母音知覚の精度向上に関する実験結果に合致 する事例が認知科学, 工学分野で複数報告されていることから, 本模倣モデルの妥当性が評価できる.

声道モデルによる認識能力向上の理由について以下のように 考察できる. RNNはコンテキスト層（隠扎状態）の自己組織化 により，類似入力に対して適切な出力を得ることができる。し かしこのコンテキスト層は, 予測誤差から学習, 自己組織化す る必要がある. 本研究の場合, $/ u /$ と $/ e /, / a /$ と $/ o /$ は音響的 には類似しており，RNNPB-1ではその区別が困難となる。こ
れに対してRNNPB-2 は，学習時に音響信号だけでなく，その 構音動作を同時に学習している。音響信号の認識時に, この構 音動作情報が適切なコンテキスト（隠れ状態）となり, 類似音響 信号を異なる構音動作として識別可能になるのだと考えられる.

本研究で利用した Maeda モデルは成人のモデルであるが, 声 道の構造，および声道駆動部位は，幼児と同様である，差異は， 声道長と駆動領域の広さであるが，本研究では『幼児が4 4 个 ぐらいで母音を発音できる状態になる』という Kuhl らの知見 から，大人のモデルを利用している．幼児から大人へ声道形状 の変化をさせた上で, 追加学習を行うことでより興味深い結果 が得られる可能性があり, 今後の課題である.

\section{2 母音判別能力}

本実験から, 少数パターンの音声・構音ダイナミクスからの 音素構造抽出可能性を示唆している. RNNPB の予測誤差に基 づく分節化手法を適用することにより，複数の時系列パターン から共通部分を PB 值として自己組織的にコード化された。 音 声模倣時にも PB 值を切り替えることにより，本システムが聴 取した多くの音声に対し，明瞭かつ弁別可能な音声を生成した。 獲得された母音構造は，定常的な母音のみならず母音間の遷移 状態をも PB 空間に自己組織化している. Fig. 11 から, PB 空 間上に時系列ダイナミクスとして各母音空間が形成されている. 母音 $/ a /$ の空間が特に広い理由は, 学習時の Maeda パラメー 夕の初期值が $/ a /$ と $/ e /$ の中間的な音であり, 結果的に初期 值から最初の母音への遷移部分が最も多くなる母音 $/ a /$ のダ イナミクスが PB 空間上に自己組織化されたからだと考えられ る. Fig. 16 に示されると扔り, 実験 2 に扔いては $/ a /$ と/e/ が PB 空間上において非常に広がりを持っている。これはラン ダムバブリング学習により自己組織化しやすい母音が現れたと 示唆される. 実際の幼児が発声する母音は $/ a /, \quad / e /$ が多く含 まれることから [33], 発達過程に適合した結果が現れていると 考えられる.

また，Fig. 12，13 に扔ける，音声認識・模倣時の PB 值の遷 移により，自己組織化した母音構造を利用した認識において話 者性に影響を受けていること, 入力音声の母音間遷移に対して 依存した認識結果が現れていることが分かる。これは，同じ母 音に対しても話者・文脈の違いよって, 本システムが内部表現 を変えて認識していることを意味する。人間の音声には調音結 合（coarticulation）という現象があり，同じ音素に対して音響 信号は一定のパターンをとらない．本システムは音声とともに 構音情報のダイナミクスを内部状態として持っており，母音音 声パターンの摇らぎに頑健な母音構造を自己組織化することが できたと示唆される。

谷らは移動ロボットに力学的アトラクタを埋め込み, 動作ダ イナミクスをシンボル化する過程を示した [34].この実験では, ロボットがアトラク夕を獲得する際，観察された対象は動作と して RNN の素子に表現される。これらのアトラク夕は RNN 上で複雑なクラス夕を形成しており，動作の文脈（移動ロボッ トの軌道）によって動作点の位置が不安定となる。このことは, 文脈依存・非依存の双方の特徵が, ダイナミクスを表現する際 に興味深い特性であることが分かる。 
Table 7 Maeda parameters of each vowel

\begin{tabular}{c||c|c|c|c|c}
\hline & $/ a /$ & $/ i /$ & $/ u /$ & $/ e /$ & $/ o /$ \\
\hline TDP & 2.0 & -2.0 & 2.0 & -1.0 & 3.0 \\
\hline LPR & -0.5 & -1.0 & 1.5 & -0.5 & 0.0 \\
\hline
\end{tabular}

\section{3 音声模倣能力}

実験 1 に対して, 全発話（210 発話）の 7 割程度の入力音声 に対し, 弁別可能な品質で明暸な模做音声を生成した。この明 瞭性判別は複数人により行ったが, 明示的基準を設けることは 現時点では難しい. Maeda モデルに特化した音響モデルによる 判定などが考えられるが今後の課題である. 各入力音声に対す る認識時の PB 值は, 学習時に自己組織化した PB 空間上の各 母音空間に対応しており, 本システムの獲得した母音構造を利 用した音声模做が可能であることを確認した，学習ずみの母音 列だけでなく, 未知の母音の組み合わせ, 音声の長さの変化に ついてもロバストに適応している.

Fig. 14 から，母音 /o/の模倣が困難であることが分かる。 ま た, 3 連続母音以上の音声模做については, 母音 $/ u /$ の模做も 困難となることが判明している，生成した模做音声の 3 割が不 明瞭であった原因は, $/ u /, / o /$ の発音間違いによるものであ る.これらの理由は, 本稿で用いた声道物理モデル Maeda モデ ルに扔いて, 母音 $/ o /, / u /$ の構音パラメー夕に対して, それ ぞれ第 2 パラメータ TDP, 第 6 パラメータ LPR が他の母音 よりも外れ值をとるからであると考えられる (Table 7 参照). 具体的には, Maeda モデルに扔ける声道の平均姿勢（標準值） は 0.0 であり, 通常, LDR は $-1.0 \sim 1.0$, TDP は $-2.0 \sim 2.0$ 程度に収まる。しかし /u/では LPR が 1.5，また/o/では TDP が 3.0 になっている。 これは実験 2 の結果についても同 様に考えられ, 実際の幼児は母音 $/ 0 /$ の生成可能となる時期が 他の母音に遅れること [33] に対応していると示唆される.

これを解決するためには, 追加学習による補正を行うことが 有力だと考えられる. 幼児が模倣可能・不可能を判別し, 親の 音声に含まれる音素を獲得していくという枠組みが本模倣モデ ルに必要である。

\section{4 幼児の発達過程との関連}

6.4 .1 幼児のバブリング学習の必要性

Imada ら [29] は, 脳磁図 (Magneto-Encephalo-Graphy : MEG）を用いて，音声と非音声（non-speech sound）に対す る子供（新生児，6ヶ月，12ヶ月）の脳反応を比較した，MEG を用いたのは, 音声知覚に対して, 聴覚関連領野 (上側頭のウェ ルニッケ野) や運動関倸領野 (下前頭のブローカ野) の応答を調 ベるためである，実験の結果，すべての年齢群について，すべ ての音刺激に対してウェルニッケ野は反応を示した。一方，ブ ローカ野は新生児ではいずれの刺激に対しても活動しなかった。 しかし, 生後 6r月以降では, 音声によってブローカ野が活動す るのみならず, 聴覚関連領野と運動関係領野（ブローカ野）の 活動が精密に同期していることが分かった。この結果は, 乳児 が声を出すこと（vocalizing）を練習するという経験によって, 発声行為と知覚が結びついていくことを示唆している。ブロー 力野は社会的認知に関与している部分であり, 人間以外の霊長 類の脳では, この部分の相同部位に「ミラーニューロン」[35] が
存在している.つまり, 乳児の時点から発声と知覚に関して密 接なかかわりがすでに存在して㧍り, 本稿の「幼児の自己発話 練習（バブリング, 音声模做）が音素獲得 音声知覚に必要であ る」という仮説を裏付ける研究結果であると言える。

\section{4 .2 構音発達との関連}

Ijiri [36] は, 幼児の言い間違い (幼児音化) の研究を行い,「バ ブリングによる学習は構音器官の一部を極端に運動させること で実現でき, 微細な運動を必要としないものである」と考察し ている. 本稿に打いても, 構音器官の極端な運動がより模做が 行いやすくなる可能性を示唆している. 5.2.2 項に, 2 種類のラ ンダムバブリング学習条件による音声模倣の結果を示している. 実験の結果, 顎の位置を下げ, 舌の前後運動と唇の開閉の差が 大きいバブリング条件において模做音声が明瞭に聞こえること が確認できた。

\section{7.おわりに}

本稿では，音声を連続音響信号として扱う音声模做モデルを 構築し，その模倣モデルを用いた音素獲得シミュレーションを 行った。本模做モデルは, 人工神経回路モデル RNNPB を用 い, 身体拘束としての構音動作と, それにより生成される音響 信号の結び付きを学習している，さらに, RNN の予測可能性に 基づく分節化手法を適用することで，複数話者に対してロバス 卜な音素構造を獲得した。

本研究は将来, 認知発達心理学・脳神経科学分野との融合を 罒ることで, 言語の発生・起源についての知見だけではなく, 第 二言語学習に扔ける発声練習の補助や構音発達障害の原因解明, 擬音語研究に対する知見などが得られることを期待できる.

今後の課題として, 模做音声の追加学習手法を構築する必要 があると考える，周囲（親など）の音素環境を発達的に獲得し ていく枠組を追加する，幼児が一時期の構音・音声学習によっ て音素を獲得しているとは考えにくい. 幼览の初期言語発達過 程の再現するため, 一度の学習のみで母音構造を獲得するので はなく, 実際の母子間インタラクションに近い母音獲得の実現 を目指す。

謝 辞 本研究は, 科学研究費, 学術創成研究「記号過程を 内包した動的適応システムの設計論」, 基盤研究 $(\mathrm{S})$, グローバ ル $\mathrm{COE}$ の支援を受けた。

\section{参 考 文 献}

[1] A. Cangelosi and D. Parisi (eds.): Simulating the Evolution of Language. Springer Verlag, 2002.

[2] L. Steels: "Evolving grounded communication for robots," Trends in Cognitive Science, vol.7, no.7, pp.308-312, 2003.

[ 3 ] L. Fadiga, L. Craighero, G. Buccino and G. Rizzolatti: "Speech listening specifically modulates the excitability of tongue muscles: a tms study," European Journal of Cognitive Neuroscience, vol.15, pp.399-402, 2002.

[4] G. Hickok, B. Buchsbaum, C. Humphries and T. Muftuler: "Auditory-motor interaction revealed by fmri," Area Spt. Journal of Cognitive Neuroscience, vol.15, no.5, pp.673-682, 2003.

[ 5 ] M. Asada, K.F. MacDorman, H. Ishigro and Y. Kuniyoshi: "Cognitive developmental robotics as a new paradigm for the design of hu-manoid robots," Robotics and Autonomous Systems, pp.185-193, 2001. 
神田尚尾形哲也高橋

6 ] R. Pfeifer and C. Scheier: Understanding Intelligence. The MIT Press, 1999.

[7] C. Breazeal and B. Scassellati: "Infant-like Social interactions between a Robot and a Human Caregiver," Adaptive Behavior, vol.8, no.1, pp.49-74, 2000.

[8] Y. Kuniyoshi and S. Sangawa: "Early motor development from partially ordered neural-body dynamics: experiments with a cortico-spinal-musculo-skeletal model," Biological Cybernetics, vol.95, no.6, pp.589-605, 2006.

[ 9 ] 早川勝廣：“言語獲得と育児語”, 月刊言語, vol.35, no.9, pp.62-67, 2006.

[10] B. de Boer: "Self-organization in vowel systems," Journal of Phonetics, vol.28, no.4, pp.441-465, 2000.

[11] P.Y. Oudeyer: "The Self-Organization of Speech Sounds," Journal of Theoretical Biology, vol.233, no.3, pp.435-449, 2005.

[12] K. Miura, Y. Yoshikawa and M. Asada: "Unconscious anchoring in maternal imitation that helps find the correspondence of a caregiver's vowel categories," Advanced Robotics, vol.21, no.13, pp.1583-1600, 2007.

[13] H. Sawada, M. Kitani and Y. Hayashi: "A Robotic Voice Simulator and the Interactive Training for HearingImpaired People," Biomedicine and biotechnology, vol.2008, doi:10.1155/2008/768232, 2008.

[14] P.K. Kuhl, B.T. Conboy, S. Coffey-Corina, D. Padden, M. Rivera-Gaxiola and T. Nelson: "Phonetic learning as a pathway to language: new data and native language magnet theory expanded (NLM-e)," Philosophical Transactions of the Royal Society B: Biological Sciences, vol.363, no.1493, pp.979-1000, 2008.

[15] J. Tani and M. Ito: "Self-organization of behavioral primitives as multiple attractor dynamics: a robot experiment," IEEE Transactions on Systems, Man, and Cybernetics, Part A, vol.33, no.4, pp.481-488, 2003.

[16] H. Kanda, T. Ogata, K. Komatani and H.G. Okuno: "Vocal Imitation Using Physical Vocal Tract Model," IEEE/RSJ IROS-2007, 2007.

[17] T. Ogata, M. Murase, J. Tani, K. Komatani and H.G. Okuno: "Two-way Translation of Compound Sentences and Arm Motions by Recurrent Neural Networks," IEEE/RSJ IROS-2007, 2007 .

[18] J. Dang, K. Akagi and K. Honda: "Communication between speech production and perception within the brain - Observation and Simulation," Journal of Computer Science and Technology, vol.21, no.1, pp.95-105, 2006.

[19] S. Hiroya, T. Mochida and M. Kashino: "Articulatory gestures, not auditory frequency resolution, determine formant frequency discrimination thresholds in vowels," Proceedings of The 29th MidWinter Meeting of the Association for Research in Otolaryngology (ARO), p.249, 2006.

[20] Y. Qiao, N. Shimomura and N. Minematsu: "Unsupervised Optimal Phoneme Segmentation: Objectives, Algorithm and Comparisons," Proceedings of the IEEE International Conference on Acoustics, Speech and Signal Processing (ICASSP2008), pp.3989-3992, 2008.

[21] S. Maeda: 'Compensatory Articulation during Speech: Evi-
徹 駒 谷 和 範 奥 乃博

dence from the Analysis and Synthesis of Vocal-Tract Shapes using an Articulatory Model,' Speech production and speech modeling (W.J. Hardcastle and A. Marchal (eds.)). pp.131-149, Kluwer Academic Publishers, 1990.

[22] N. Kitawaki, F. Itakura and S. Saito: "Optimum coding of transmission parameters in PARCOR speech analysis synthesis system," Transactions of the Institute of Electronics and Communication Engineers of Japan (IEICE), vol.J61-A, no.2, pp.119-126, 1978.

[23] T. Fukuda, K. Tokuda, T. Kobayashi and S. Imai: "An adaptive algorithm for mel-cepstral analysis of speech," Proceedings of the IEEE International Conference on Acoustics, Speech and Signal Processing (ICASSP-1992), pp.137-140, 1992.

[24] H. Kawahara, K. Masuda and A. de Cheveigne: "Restructuring speech representations using a pitch-adaptive time-frequency smoothing and an instantaneous-frequency-based F0 extraction," Speech Communication, vol.27, pp.187-207, 1999.

[25] D. Rumelhart, G. Hinton and R. Williams: Learning internal representation by error propagation. The MIT Press, 1986.

[26] A.M. Liberman and I.G. Mattingly: "The motor theory of speech perception revised," Cognition, vol.21, pp.1-36, 1985.

[27] M.E.H. Schouten: "The case against a speech mode of perception," Acta Psychologica, vol.44, pp.71-98, 1980.

[28] M. Kashino: "The motor theory of speech perception: Its history, progress, and perspective," The Acoustical Society of Japan, vol.62, no.5, pp.391-396, 2006.

[29] T. Imada, Y. Zhang, M. Cheour, S. Taulu, A. Ahonen and P.K. Kuhl: "Infant speech perception activates Broca's area: A developmental magnetoenceohalography study," Neuroreport, vol.17, pp.957-962, 2006

[30] H. Kanda, T. Ogata, K. Komatani and G.H. Okuno: "Vocal Imitation Using Physical Vocal Tract Model," Proceedings of IEEE/RSJ International Conference on Intelligent Robots and Systems (IROS-2007), pp.1846-1851, 2007.

[31] X. Lu and J. Dang: "Speech recognition based on a combination of acoustic features with articulatory information," Chinese Journal of Acoustics, vol.24, no.3, pp.271-279, 2005.

[32] 江尻桂子： “言語獲得の基盤としての乳児の音声発達（話す仕組みを 巡って: 発話機構研究の最前線)", 日本音響学会誌, vol.55, no.11, pp.789-795, 1999.

[33] 石塚健太郎, 麦谷綾子, 天野成昭：“F1-F2 平面上に打ける成人母音 からの距離に基づく幼児母音の月齢変化”, 日本音響学会講演論文集, pp.335-336, 2005.

[34] J. Tani: "Model-based learning for mobile robot navigation from the dynamical systems perspective," IEEE Trans. on Systems, Man, and Cybernetics Part B: Cybernetics, vol.26, no.3, pp.421-436, 1996.

[35] G. Rizzolatti: "The mirror neuron system and imitation," Perspectives on Imitation: From Neuroscience to Social Science (S. Hurley and N. Chater (eds.)) vol.1. pp.55-76, The MIT Press, 2005.

[36] M. Ijiri: Mechanism of Children's Deviation from Adult Articulation Forms in the Articulatory Learning Model, Master's thesis, Department of Intelligence Science and Technology Graduate School of Informatics, Kyoto University, 2007. 


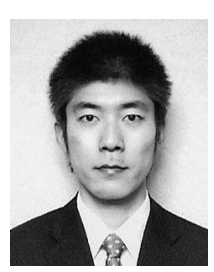

神田 尚（Hisashi Kanda）

2007 年京都大学工学部情報学科卒業, 2009 年同大 学情報学研究科知能情報学専攻修士課程修了, 現在 富士通株式会社勤務。情報処理学会第 70 回, 第 71 回全国大会学生奨励賞受賞. 情報処理学会会員.

（日本ロボット学会学生会員）

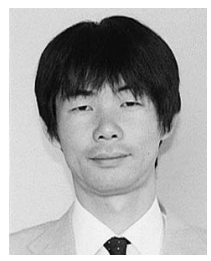

\section{高橋 徹（Toru Takahashi）}

1996 年名古屋工業大学知能情報システム学科卒業. 2004 年名古屋工業大学大学院工学研究科電気情報 工学専攻, 博士後期課程修了. 博士 (工学). 和歌 山大学 システム工学部産学官連携研究員を経て, 2008 年より京都大学大学院情報学研究科グローバ ル COE 助教。研究分野は, ロボット聴覚および音 声コミュニケーション。音声による人間ーロボット間インタラクショ ンのための音声認識・合成. ロボット聴覚ソフトウェア HARK, 音 声分析変換合成システム STRAIGHT の開発. IPSJ, IEICE，ASJ などの会員

（日本ロボット学会正会員）

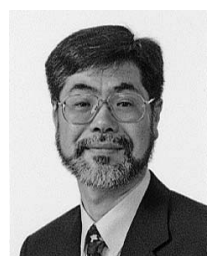

\section{奥乃 博 (Hiroshi G. Okuno)}

1972 年東京大学教養学部基礎科学科卒業. 日本電 信電話公社, NTT, 科学技術振興事業団, 東京理科 大学を経て, 2001 年より京都大学大学院情報学研 究科知能情報学専攻教授, 博士 (工学)。この間, 又 タンフォード大学客員研究員, 東京大学工学部客員 助教授、人工知能, 音環境理解, ロボット聴覚, 音 楽情報処理の研究に従事. 1990 年度人工知能学会論文賞, IEA/AIE2001，2005 最優秀論文賞, IEEE/RSJ IROS-2001, 2006 Best Paper Nomination Finalist, IROS-2008 Award for Entertainment Robots and Systems Nomination Finalist 2 件，第 2 回船井情報 科学振興賞等受賞. 人工知能学会, 日本ソフトウエア科学会, ACM, IEEE，AAAI，ASA などの会員。（日本ロボット学会正会員）

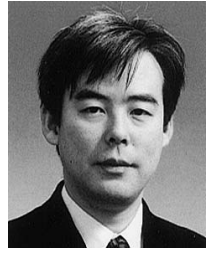

尾形哲也（Tetsuya Ogata）

1993 年早稲田大学理工学部機械工学科卒業. 日本 学術振興会特別研究員, 早稲田大学理工学部助手, 理化学研究所脳科学総合研究センター研究員, 京都 大学大学院情報学研究科講師を経て, 2005 年より 同助教授 (現·准教授). 博士 (工学)。この間, 2005 年より早稲田大学ヒューマノイド研究所客員准教授, 2006 年より理化学研究所脳科学総合研究センター客員研究員を兼務. 研究分野は人工神経回路モデルおよび人間とロボットのコミュニケー ション発達を考えるインタラクション創発システム情報学. 2001 年日 本機械学会論文賞, IEA/AIE-2005 最優秀論文賞などを受賞. JSME, JSAI，SICE，IEEE などの会員.

（日本ロボット学会正会員）

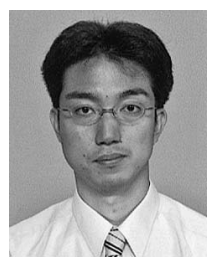

駒谷和範（Kazunori Komatani）

1998 年京都大学工学部情報工学科卒業. 2000 年同 大学大学院情報学研究科知能情報学専攻修士課程修 了. 2002 年同大学大学院博士後期課程修了. 同年 京都大学情報学研究科助手. 2007 年より助教, 現 在に至る。京都大学博士 (情報学)。主に音声対話 システムの研究に従事. 2008 年から 2009 年まで 米国カーネギーメロン大学客員研究員. 情報処理学会平成 16 年度山 下記念研究賞, FIT2002 ヤングリサーチャー賞等受賞. 情報処理学 会, 電子情報通信学会, 言語処理学会, 人工知能学会, ACL, ISCA などの会員 